\title{
NITRATE CONTENT IN FRUITS AND VEGETABLES FROM COMMERCIAL CHAINS IN BULGARIA
}

\author{
Snejana Dineva \\ Department of Food Technology, Faculty of Technics and Technologies of Yambol, \\ Trakia University of Stara Zagora, Bulgaria \\ Graf Ignatiev 38, 8600 Yambol, Bulgaria \\ mobile: +359898999457, e-mail: snezhana.dineva@trakia-uni.bg
}

\begin{abstract}
The aim of this monitoring is to evaluate the nitrate content in vegetables and fruits from the commercial chain in Bulgaria. The vegetables were purchased from the food chains in June and July. The measurements of $\mathrm{NO}_{3}{ }^{-}$ions were carried out with a Greentest appliance, Model ECO 5. Four samples from the conducted monitoring were with higher $\mathrm{NO}_{3}^{-}$amount that is allowed for trade and accepted as healthy (potato, radish, and strawberries). The content of $\mathrm{NO}_{3}^{-}$in fresh potato were 645 $\mathrm{mg} / \mathrm{kg}$ at the accepted safety level $250 \mathrm{mg} / \mathrm{kg}$. The level of nitrates also was higher in the both samples of radish $3700 \mathrm{mg} / \mathrm{kg}$ and $2934 \mathrm{mg} / \mathrm{kg}$ at accepted level as safety for consumption 1500 $\mathrm{mg} / \mathrm{kg}$. This small survey suggests that on the market in the country are still in the trade food products with not enough good quality.
\end{abstract}

Keywords: nitrates, food safety, vegetables, fruits.

\section{INTRODUCTION}

Nitrates as most of the other inorganic substances are relatively toxic and the health effect depended mostly of the amount that is digested. The content of $\mathrm{NO}_{3}{ }^{-}$is an important quality characteristic of vegetables, because they constitute the major source that formed daily dietary intake from 300 to $940 \mathrm{mg} / \mathrm{g}$ [1], more than $80 \%$ of dietary nitrates consumption [2], [3], and [4].

Nonetheless, of restrictions and regulations accepted to control and minimize nitrate intake from human food, there are still vegetables on the EU market with exceeded levels. The assessment of human population nitrate exposure in Italy confirm that the acceptable daily intake was higher than the settled limits of $3.7 \mathrm{mg} / \mathrm{kg}$ bw per day and that the ingestion of nitrates from vegetables mainly generate the highest exposure to people of all ages [5].

The current study aims to evaluate the nitrate content in the vegetables and fruits from the commercial chain in BG during summer season.

\section{METHODS}

The vegetables were purchased from the food chains in June and July. The measurements of $\mathrm{NO}_{3}{ }^{-}$ions were carried out with a Greentest appliance, Model ECO 5, for measuring the level of nitrates in fresh fruits and vegetables, as well as harmful substances contained in meat and fish. The appliance is certified and calibrated based on more than 1,000 studies of leading labs using spectrometric equipment. It has certificates: SGS, CCIC-SET, EMC, LVD, and SQC. Min/max amount of measured nitrate concentration: 0-9999 mg/ kg, with permissible error: $<10 \%$. 


\section{EXPERIMENTAL}

All samples were vegetables and fruits bought from the food chain supermarkets in BG, but not all of them were with clarified origin, nevertheless all of them had permission to be sell in EU market. The strawberries (2) sample was from Bulgaria, Plovdiv. The radish (1) sample was from Italy.

All measurements were repeated ten times per sample, processed with Excel using ANOVA - one tail, and standard descriptive analysis. The averaged values with variables, minimum and maximum in a single sample are represented in the results.

\section{RESULTS AND DISCUSSION}

The investigation is part of the research project with the goal to evaluate and screen the quality of the food from BG market. In order to assess the nitrate content of vegetables in the $\mathrm{BG}$ market, the random monitoring was conducted several times in different seasons. The results from the assay conducted June and July are represented in the Table 1.

Table 1. Nitrates content in vegetables (Measurements June \& July, 2019)

\begin{tabular}{|l|c|c|c|c|c|c|}
\hline $\begin{array}{l}\text { Nutritional } \\
\text { product }\end{array}$ & $\begin{array}{c}\text { Acceptable } \\
\text { level for } \\
\text { consumption } \\
{[\mathrm{mg} / \mathrm{kg}]}\end{array}$ & $\begin{array}{c}\text { Average } \\
\text { measured } \\
\text { amount } \\
{[\mathrm{mg} / \mathrm{kg}]}\end{array}$ & $\begin{array}{c}\text { Min } \\
\text { value } \\
{[\mathrm{mg} / \mathrm{kg}]}\end{array}$ & $\begin{array}{c}\text { Max } \\
\text { value } \\
{[\mathrm{mg} / \mathrm{kg}]}\end{array}$ & $\begin{array}{c}\text { Standard } \\
\text { Deviation } \\
{[\mathrm{mg} / \mathrm{kg}]}\end{array}$ & $\begin{array}{c}\text { Coefficient } \\
\text { of variation } \\
\%\end{array}$ \\
\hline Fresh potatoes & 250 & $645^{*}$ & 390 & 900 & 160.78 & $24 \%$ \\
\hline Carrots & 400 & $<30$ & $<30$ & 50 & $\mathrm{~N} / \mathrm{A}$ & $\mathrm{N} / \mathrm{A}$ \\
\hline Radish (1) & 1500 & $3700^{*}$ & 2100 & 7900 & 1675 & $45 \%$ \\
\hline Radish (2) & 1500 & $2934^{*}$ & 840 & 5300 & 1214 & $41 \%$ \\
\hline Tomatoes & 300 & 48 & $<30$ & 90 & 32.12 & $33 \%$ \\
\hline Strawberries (1) & 100 & $148^{*}$ & 40 & 300 & 102.72 & $69 \%$ \\
\hline Strawberries (2) & 100 & 58.33 & 40 & 90 & 19.40 & $33 \%$ \\
\hline Banana & 200 & 95 & $<30$ & 200 & 52.75 & $56 \%$ \\
\hline Cucumber & 400 & 38 & $<30$ & 60 & 11.35 & $30 \%$ \\
\hline Onion & 80 & 32.5 & $<30$ & 45 & 5.40 & $17 \%$ \\
\hline Cherry & 50 & $<30$ & N/A & N/A & N/A & N/A \\
\hline Apricot & 60 & $<30$ & N/A & N/A & N/A & N/A \\
\hline
\end{tabular}

*- exceed it the acceptable value;

According to the nitrate content, the vegetables are classified in 5 groups:

- Very low (<200 $\mathbf{~ m g / k g ) ~ - ~ P e a , ~ S w i s s ~ c h a r d , ~ P e p p e r , ~ P o t a t o , ~ S u m m e r ~ s q u a s h , ~ S w e e t ~}$ potato, Tomato, Watermelon, Mushroom, Melon, Green bean, Onion, Garlic, Brussels sprouts Eggplant, Broad bean, Asparagus, Artichoke;

- Low (200-500 mg/kg) - Broccoli, Carrot, Cauliflower, Cucumber, Pumpkin, 'Puntarelle' chicory;

- Middle (500-1000 $\mathbf{~ m g / k g ) ~ - ~ C a b b a g e , ~ S a v o y ~ c a b b a g e , ~ T u r n i p , ~ D i l l ~ ( A n e t h u m ~}$ graveolens);

- High (1000-2500 mg/kg) - Parsley, Leek, Leaf chicory, Kohlrabi (Brassica oleracea var. gongylodes), Fennel (Foeniculum vulgare), Escarola, Endive (Cichorium endivia), Chinese cabbage, Celeriac;

- Very high (>2500 $\mathbf{~ m g / k g ) ~ - ~ R o c k e t , ~ S p i n a c h , ~ S w i s s ~ c h a r d , ~ R e d ~ b e e t r o o t , ~ R a d i s h , ~}$ Lettuce (Lactuca sativa), Lamb's lettuce, Cress (Lepidium sativum), Chervil (Anthriscus cerefolium), Celery (Apium graveolens).

IRTIIE Vol. 7, No. 2, 2019 ISSN 1314-8788 (print), ISSN 1314-8796 (online), doi: 10.15547/artte.2019.02.009 


\section{ARITIE}

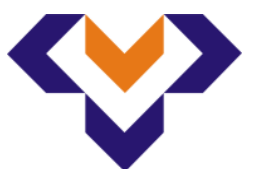

Ipplied Resseirlches in Teednicis, Technologies and Eductation

Journal of the Faculty of Technics and Technologies, Trakia University https://sites.google.com/a/trakia-uni.bg/artte/

Vegetables with high contend of nitrates belong to families that accumulate nitrates as Brassicaceae (rocket, radish, mustard), Chenopodiaceae (beetroot, Swiss chard, spinach) and Amarantaceae; and also Asteraceae (lettuce) and Apiaceae (celery, parsley) known as species with high nitrate contents [1].

For the assessment were chosen vegetables from different classes according to the nitrate content and groups that are listed above. Four samples from the conducted monitoring were with higher $\mathrm{NO}_{3}{ }^{-}$amount that is recommended (Table 1, Figures 1 and 2).

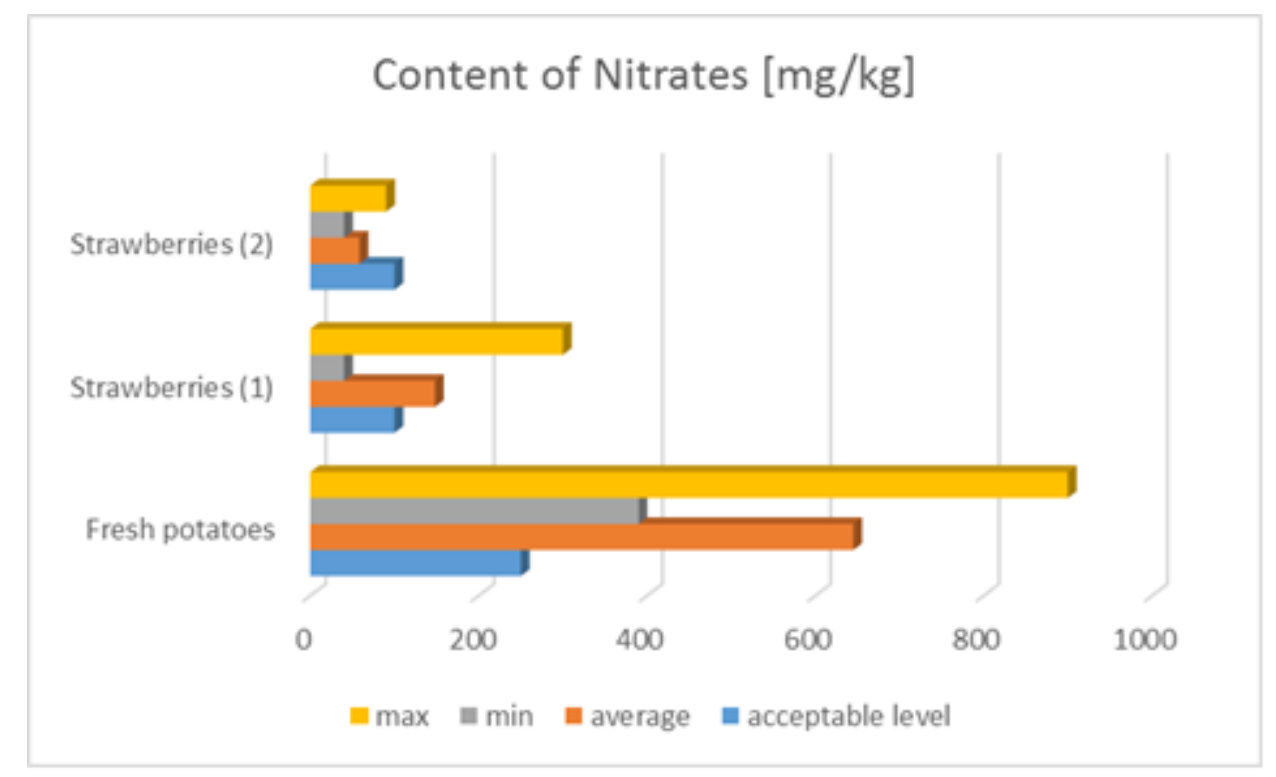

Figure 1. Content of Nitrates in vegetables from

commercial chains in BG - listed as vegetables with middle nitrate content

Table 2. Maximum levels for $\mathrm{NO}_{3}^{-}[\mathrm{mg} / \mathrm{kg}]$ in some vegetables

\begin{tabular}{|c|c|c|c|}
\hline & & \multicolumn{2}{|c|}{ Maximum levels $\mathrm{NO}_{3}^{-}[\mathrm{mg} / \mathrm{kg}]$} \\
\hline 1.1 & Fresh spinach (Spinacia oleracea) & & 3500 \\
\hline 1.2 & Preserved, deep-frozen or frozen spinach & & 2000 \\
\hline 1.3 & $\begin{array}{l}\text { Fresh Lettuce (Lactuca sativa L.) } \\
\text { (protected and open-grown lettuce) } \\
\text { excluding lettuce listed in point } 1.4\end{array}$ & $\begin{array}{l}\text { Harvested } 1 \text { October to } 31 \text { March: } \\
\text { lettuce grown under cover } \\
\text { lettuce grown in the open air } \\
\text { Harvested } 1 \text { April to } 30 \text { September: } \\
\text { lettuce grown under cover } \\
\text { lettuce grown in the open air }\end{array}$ & $\begin{array}{l}5000 \\
4000 \\
4000 \\
3000\end{array}$ \\
\hline 1.4 & ‘Iceberg’ type lettuce & $\begin{array}{l}\text { Lettuce grown under cover } \\
\text { Lettuce grown in the open air }\end{array}$ & $\begin{array}{l}2500 \\
2000\end{array}$ \\
\hline 1.5 & 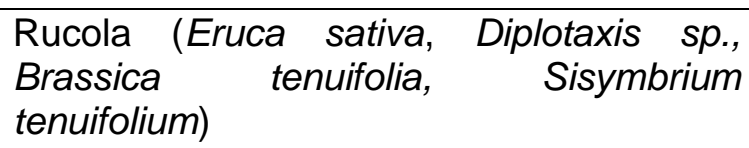 & $\begin{array}{l}\text { Harvested } 1 \text { October to } 31 \text { March: } \\
\text { Harvested } 1 \text { April to } 30 \text { September: }\end{array}$ & $\begin{array}{l}7000 \\
6000\end{array}$ \\
\hline 1.6 & $\begin{array}{l}\text { Processed cereal-based foods and baby } \\
\text { foods for infants and young children }\end{array}$ & & 200 \\
\hline
\end{tabular}

IRTIIE Vol. 7, No. 2, 2019 ISSN 1314-8788 (print), ISSN 1314-8796 (online), doi: 10.15547/artte.2019.02.009 


\section{ARTIIE

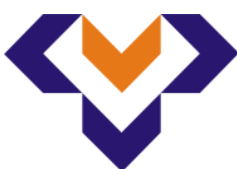 \\ Ipplied Resseirlohes in Technics, Technologies and Bductation \\ Journal of the Faculty of Technics and Technologies, Trakia University https://sites.google.com/a/trakia-uni.bg/artte/}

Commission Regulation (EU) No 563/2002 sets limits for nitrates only for leafy vegetables, which was amended two times in 2006 (EC Regulation No 1882/2006) and in 2011 with Commission Regulation (EU) No 1258/2011 (Table 2).

In some countries are set limits to maximum levels of nitrate for trade of some vegetables (beetroot, cabbage, carrot, celery, endive, Lamb's lettuce, potato, radish and rocket) which form the main source of total dietary exposure of nitrate [1]. For example, for potato in Germany the content should be less than $200 \mathrm{mg} / \mathrm{kg}$ fresh matter (fm), while in Poland there is a maximum limit of $183 \mathrm{mg} / \mathrm{kg} \mathrm{fm}$. In that study the content of $\mathrm{NO}_{3}{ }^{-}$in fresh potato were $645 \mathrm{mg} / \mathrm{kg}$ at the accepted safety level $250 \mathrm{mg} / \mathrm{kg}$ (Figure 1).

The level of nitrate in radish was higher in the both samples (Table 1), $3700 \mathrm{mg} / \mathrm{kg}$ and 2934 $\mathrm{mg} / \mathrm{kg}$ at accepted as safety level for consumption $1500 \mathrm{mg} / \mathrm{kg}$ (Figure 2).

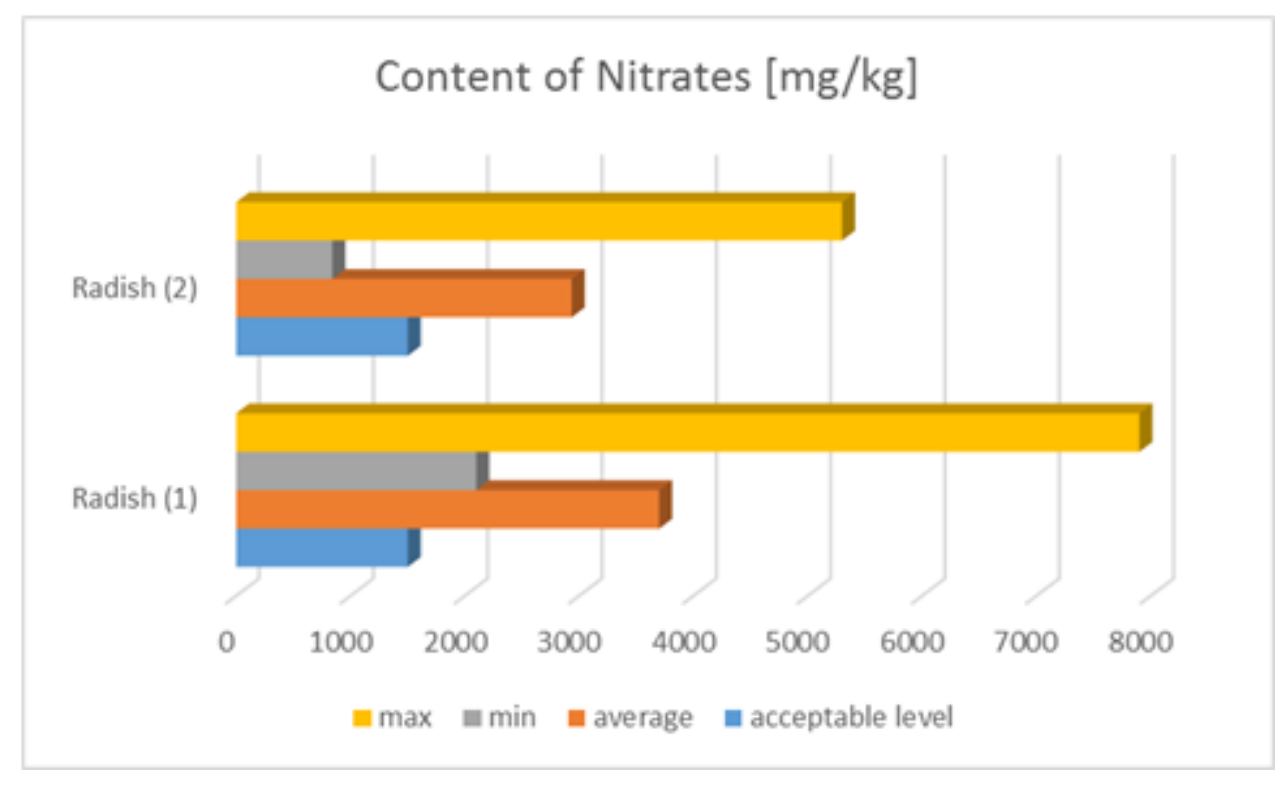

Figure 2. Content of Nitrates in vegetables from commercial chains

in BG - listed as vegetables with high content of nitrates

The reduction of nitrates in the radish sample was insignificant about $153 \mathrm{mg} / \mathrm{kg}$, after holding in water and splashed few times for 24 hours. The reduction of dietary nitrate consumption is a desirable preventive measure of potential long-term human health risks, and that will rise the benefit of fruit and vegetable digestion [1]. Hence, with applying good practices for agriculture cultivation and with the increasing of the control and monitoring programmes that can be handle and done in the future.

\section{CONCLUSIONS}

The obtained results undoubtedly confirm that on the food chain market in BG are still in the trade food products with not enough good quality, besides of the monitoring inspections and the tidy control that exist.

The Greentest appliance, Model ECO 5 give possibility to check the nitrate content in very easy and quickly manner that allow to screen and obtain reliable big data for short time.

The programmes for monitoring and control should be inevitable part of that contest for better and healthy food, as well as spreading the results from effective good agriculture practices. 


\section{IRTTE Ipplied Researrohes in Technics, Technologies and Bducition Journal of the Faculty of Technics and Technologies, Trakia University https:///ites.google.com/a/trakia-uni.bg/artte/}

\section{ACKNOWLEDGMENTS}

The work in this article is covered by Project No 3.FTT/ 22.05.2018 on "Evaluation of the ecological purity of food raw materials and products".

\section{REFERENCES}

[1] Santamaria Pietro. (2006). Review. Nitrate in vegetables: toxicity, content, intake and EC regulation. J Sci Food Agric 86:10-17 (2006). doi: 10.1002/jsfa.

[2] Hord N. G., Tang Y., Bryan N. S. (2009). Food sources of nitrates and nitrites: the physiologic context for potential health benefits. American Journal of Clinical Nutrition. 2009; 90: 1-10.

[3] Brkić D., J. Bošnir, M. Bevardi, A. Gross Bošković, S. Miloš, D. Lasić, A. Krivohlavek, A. Racz, A. Mojsović-Ćuić, N. Uršulin Trstenjak. (2017). Nitrate in leafy green vegetables and estimated intake. Brkic et al., Afr J Tradit Complement Altern Med., (2017) 14 (3): 31-41. doi: 10.21010/ajtcam. v14i3.4.

[4] Ranasinghe R. A. S. N., and R. A. U. J. Marapana. (2018). Nitrate and nitrite content of vegetables: A review. Journal of Pharmacognosy and Phytochemistry 2018; 7(4): 322328.

[5] Roila R., R. Branciari, B. Staccini, D. Ranucci, D. Miraglia, M. S. Altissimi, M. L. Mercuri, and N. M. Haouet. (2018). Contribution of vegetables and cured meat to dietary nitrate and nitrite intake in Italian population: Safe level for cured meat and controversial role of vegetables. Ital J Food Saf. 2018 Sep 26; 7(3): 7692. Published online 2018 Nov 7. doi: 10.4081/ijfs.2018.7692. 